\title{
Measuring Entrepreneurial Intention among University Students through Informal Education and Entrepreneurial Mindset
}

\author{
Widjojo Suprapto ${ }^{1}$, Dhyah Harjanti ${ }^{2}$, Vernando Yosua Ginantha ${ }^{3}$ \\ \{joe.suprapto@petra.ac.id ${ }^{1}$,dhyah@petra.ac.id², vernando.yosua@gmail.com ${ }^{3}$ \} \\ Petra Christian University, Siwalankerto 121-131 123
}

\begin{abstract}
This is a preliminary study to look at the undergraduate students of Petra Christian University, whose major are not learning business and economics, whether they are eager to become entrepreneurs after being influenced by their family, peer groups, friends or other influential social factors. In this study, the social factors are considered as creating the informal education. The study also looks at the personal factors, which are reflected in their mindset and grit. The students, whose parents are mostly business owners, have a high intention to become entrepreneurs. As the data were collected from 103 students using questionnaires, the result shows that informal education and mindset have significant influences on entrepreneurial intention. Grit, or perseverance and persistence, strengthens the relationship between informal entrepreneurial education and entrepreneurial intention. However, grit does not play any effect on the relationship between entrepreneurial mindset and entrepreneurial intention.
\end{abstract}

Keywords: informal education, business mindset, business owner intention

\section{Introduction}

Without entrepreneurs and their businesses, there would be little rooms for innovations, slow growth in productivity, and a few new job opportunities. The intention to become entrepreneurs is relatively low for Indonesian youth compared to other Asian countries, although entrepreneurs are needed to boost the economic growth which will later increase the prosperity of the society members [1]. Based on the Global Entrepreneurship Index ranking, Indonesia has improved its position from $94^{\text {th }}$ in 2018 to $75^{\text {th }}$ in 2019 , although Indonesia is still below Singapore, Malaysia, Brunei Darussalam, Thailand, and Vietnam [2]. The result of the survey indicates a significant growth of entrepreneurship in Indonesia, such as the opportunity, infrastructures, and supports.

According to Gjorgjieska et al. [3], entrepreneurial education is believed to enable to stimulate the entrepreneurial intention by changing mindsets and providing necessary skills. Entrepreneurial education is defined as all forms of learning and training, both formal and informal, which shape the entrepreneurial mindset and spirit by learning with or without commercial objectives [4]. UNESCO defines informal education as "any organized and sustained educational activities that take place both within and outside educational institutions, and cater to persons of all ages" [3]. Most studies have confirmed the significant impacts of formal education on entrepreneurial mindset [5] although they also recognize the strong influence of family role model on building the entrepreneurial intention [6]. Yet, only limited studies are devoted to the importance of informal education in stimulating the entrepreneurial mindset [7]. 
Duckworth and Quinn [8] introduced the concept of grit, which comprises of will power, passion, perseverance and persistence, as the fuel to achieve long term objectives. Since then, many researchers debate the idea of grit in the entrepreneurship [9]. Some researches raise also the role of passion, instead, as the trigger for the entrepreneurial intention [5]. Some others argue that passion alone is not strong enough to endure the uncertainty of business environment, and propose other factors such as perseverance, and persistence [10].

Based on several talks with some university graduates, many of them run their own businesses or take over their family businesses after devoting some of their time in big corporations. According to them, their entrepreneurship is most likely shaped by their family and surroundings, regardless their university degrees. Many with no business studies background, they venture their entrepreneurial experiences by learning from more experienced family, friends, peer groups, medias, and seminars. Therefore, it is interesting to explore how the informal entrepreneurial education affects the entrepreneurial intention.

This is a preliminary study looking at the entrepreneurial intention among the university students who take all majors except business and economics. The subject for this study is the undergraduate students from Petra Christian University (PCU), in Surabaya. The students are coming from a strong family business background, because majority of their parents are selfemployed and business owners. Many of the alumni run their own businesses which are not related with their studies and degrees, after working several years for others. This study is measuring the entrepreneurial intention among them.

\section{Literature Review}

\subsection{Informal entrepreneurial education}

Rogoff et. al. [11] explain informal education as educational activities which happen outside the school (formal education), such as among the peer groups, the family, and the social media. Informal education is a learning activity from individual initiatives with the aim to increase personal needs of knowledge and expertise [12]. Based on this definition, informal entrepreneurial education is defined as the learning process about entrepreneurship carried out with the initiative of those who want to achieve the desired level of knowledge and expertise outside formal educational settings. According to Jeong et. al. [12], informal education is measured with these indicators: learning competence, intentionality, and developmental relatedness.

\subsection{Entrepreneurial mindset}

Entrepreneurial mindset is described by scholars as "the ability to rapidly sense, act, and mobilize under uncertain conditions [13]. Haynie et al. [14] elaborate the definition into "the ability to be dynamic, flexible, and self-regulating in one's cognitions given dynamic and uncertain task environments". According to Solesvik et al. [15], an entrepreneurial mindset is built on alertness that "facilitates rapid discovery and exploitation of opportunities, although they are highly uncertain". Therefore, entrepreneurial mindset is a way of thinking and behavior pattern that are possessed by an entrepreneur in order to be able to take advantage of various opportunities and to benefit from various uncertain situations. Nauman [16] measured entrepreneurial mindset with these indicators: cognitive tuning and goal orientation, heuristic- 
based decision logic, alertness, prior knowledge, social interaction, meta-thinking, and cognitive adaptability.

\subsection{Grit}

According to Duckworth and Gross [17], grit is a character trait demonstrated through behavior pattern to maintain perseverance and enthusiasm in efforts to achieve the expected long-term goals. Grit is often evaluated as a form of strong determination to not giving up while striving to reach the goal. The meaning of grit is also explained by Butz et al. [9] as behavior shown by someone in order to be able to achieve long-term goals by overcoming obstacles and challenges. According to Tirado et al. [18], grit is also understood as a striving force that describes a strength in the long run to achieve certain goals despite many obstacles. Duckworth and Quinn [8] designed a measurement to evaluate the grit based on 6 items of perseverance of efforts and 6 items of consistency of interest.

\subsection{Entrepreneurial intention}

Many scholars study the entrepreneurial intention from internal factors, such as psychological traits and personal characteristics, and gradually combine external factors, such as education, family and other environmental factors [5]. Entrepreneurial intention is defined as the strong desire and ability to get involved in entrepreneurial activities or in building a new business [19]. In their study, Cao and Ngo [20] also explain that entrepreneurial intention is described as a strong or weak desire to become an entrepreneur, and the intention is reflected by the commitment and real action to commence a business and to develop the business. Entrepreneurial intention is supported by family, network, parental socio-economic, and selfefficacy [19].

\subsection{Hypothesis development}

Hou et al. found that entrepreneurial education has a significant influence on entrepreneurial intention [5]. Meanwhile, Rogoff et al. mentioned the importance of informal education in shaping one's personal interests and knowledge [11]. Geldhoff et al. recognize the strong influence of family role models on creating entrepreneurial intention [6]. Jeong et al. also indicate the informal education having a significant influence on entrepreneurial intention [12]. Therefore, the first hypothesis is constructed as follows:

H1 : It is suspected that informal entrepreneurial education influences significantly on entrepreneurial intention;

Some studies show how entrepreneurial education affects entrepreneurial mindet [7] [15]. Some researchers, then, connect entrepreneurial mindset with entrepreneurial intention [16] [19]. Cao and Ngo explain specifically the significant influences of entrepreneurial mindset on entrepreneurial intention [20]. Therefore, the second hypothesis is constructed as follows:

$\mathrm{H} 2$ : It is suspected that entrepreneurial mindset influences significantly on entrepreneurial intention;

Many studies on grit were carried out in the field of entrepreneuship after Ducksworth talked about grit in 2009. Butz et al. examined the role of grit in influencing the entrepreneurial intention among university students [9]. Singh and Chopra revealed a strong correlation between grit and intention to work [10]. Specifically, Tirado et al. proved that grit acts as a predictor for entrepreneurship and self employment [18]. Therefore, the third and fourth hypotheses are constructed as follows: 
H3 : It is suspected that grit is moderating the influence of informal entrepreneurial education on entrepreneurial intention;

H4 : It is suspected that grit is moderating the influence of entrepreneurial mindset on entrepreneurial intention.

Based on the literature review, the research framework is designed as follows:

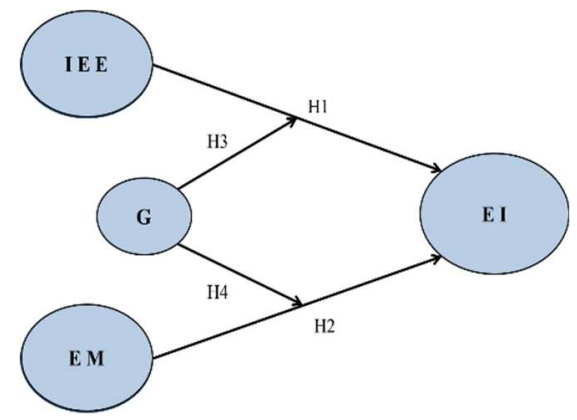

Fig.1. Research schemes

\section{Method}

This is a quantitative research in which the data are collected using questionnaires from samples of a population to measure the entrepreneurial intention. The population of this study is the third and fourth year undergraduate students of Petra Christian University. The questionnaires were distributed to 150 students from various faculties, except the faculty of business and economics, using Google form. The questionnaires were distributed in April to June 2020 , and the returned questionnaires were 103 , with the response rate of $68.7 \%$. The questionnaire consists of two parts, part one is to collect information on family background from respondents, and part two is to measure the respondents' entrepreneurial intention. The questionnaire has 39 reflective statements, that are assessed using the Likert Scale of 1 to 5, with one is very disagree to five strongly agree. The data, then, were processed with smartPLS 3.0 to obtain the outer model and the inner model.

\section{Result And Discussion}

From 103 returned questionnaires, the first part of the questionnaire shows the respondents' background. The respondents are coming from a family business background $(92.3 \%)$. The family business mostly are in retailing and wholesaling (64.1\%) and consulting services $(22.3 \%)$. The majority respondents are coming from the faculty of art \& design (29.1\%), industrial engineering (25.2\%), and architecture \& civil engineering $(20.4 \%)$. After graduation, if the respondents are opening their own businesses, they plan to start the business in retailing and wholesaling $(55.3 \%)$, services $(31.1 \%)$, and creative industry $(10.7 \%)$.

From the second part of the questionnaire, the descriptive statistic summary can be observed in Table 1. 
Table 1. Descriptive Statistic

\begin{tabular}{lcl}
\hline \multicolumn{1}{c}{ Variable } & Means & \multicolumn{1}{c}{ Remark } \\
\hline Informal Entrepreneurial Education (IEE) & 4.12 & high \\
IEE - 3 & 4.24 & very high \\
IEE - 1 & 3.85 & high \\
Enterpreneurial Mindset (EM) & 3.84 & high \\
EM - 13 & 3.99 & high \\
EM - 4 & 3.68 & high \\
Grit (G) & 3.93 & high \\
G - & 4.32 & very high \\
G -8 & 3.62 & high \\
Enterpreneur Intention (EI) & 3.80 & high \\
EI - 3 & 4.17 & high \\
EI - 1 & 3.83 & high \\
\hline
\end{tabular}

From the descriptive statistic, the respondents show high intention to become entrepreneurs (3.80) by preparing their mindset to become an entrepreneur (EI-3). Although they are not majoring in Business and Economics, the respondents score informal entrepreneurial education as high, especially the desire to learn the knowledge and skills of entrepreneurship from others (IEE-3). The entrepreneurial mindset of the respondents is considered high (3.84), which is shown by the ability to make use of others' experiences in handling his/her difficult situation (EM-13). Finally, the respondents show high score on their grit (3.93), with perseverance to focus the task (G-2) and persistence to overcome difficulties (G-8).

To examine the influences of exogenous variables on endogenous variable, the data are processed with smartPLS 3.0 to obtain the results of the outer model and inner model. The outer model is examining the relationships of each variable with its indicators, the higher the loading value of an indicator, the higher the ability of an indicator to explain its variable [21]. The outer model will present the results of the validity and reliability tests. Observing the results, all indicators have the loading value of greater than 0.60 ; therefore, all comply with the convergent validity requirement. The results from the cross loading test also shows that the value of each indicator in a variable is higher than other variables, so it fulfills the discriminant validity test. The last tests are the average variance extracted (AVE), composite reliability, and Cronbach's Alpha, which are presented in Table 2. The values of all variables are greater than 0.50 , so they are valid [22]. The composite reliability and Cronbach's alpha values are greater than 0.70 , so the variables are reliable to measure the research model [22].

Table 2. Construct validity and reliability

\begin{tabular}{lccc}
\multicolumn{4}{c}{ Table 2. Construct validity and reliability } \\
\hline \multicolumn{1}{c}{ Variable } & AVE & $\begin{array}{c}\text { Composite } \\
\text { Reliability }\end{array}$ & $\begin{array}{c}\text { Cronbach } \\
\text { Alpha }\end{array}$ \\
\hline Enterpreneur Intention & 0.765 & 0.920 & 0.956 \\
Enterpreneurial Mindset & 0.541 & 0.958 & 0.938 \\
Grit & 0.727 & 0.922 & 0.965 \\
Informal Entrepreneurial Education & 0.770 & 0.957 & 0.939 \\
\hline
\end{tabular}

The inner model shows the relationships among the variables. The relationships can be observed from the result of the R-square test, the original sample (or the path coefficient), the $\mathrm{T}$ statistics. For the hypothesis testing, the results are observable from the $\mathrm{T}$ statistics and the $\mathrm{P}$ values in Table 3. The R-square of entrepreneurial intention is 0.859 , so the variable of 
entrepreneurial intention is influenced by the variable of informal education and mindset as much as $85.9 \%$.

For the hypothesis testing, the result of the $\mathrm{T}$ statistics and $\mathrm{P}$ value can be observed in Table 3.

Table 3. Hypothesis testing

\begin{tabular}{|c|c|c|c|c|}
\hline & Hypothesis & T Statistics & P Value & Remark \\
\hline $\mathrm{H}_{1}$ & $\begin{array}{l}\text { Informal Entrepreneurial Education } \rightarrow \\
\text { Enterpreneur Intention }\end{array}$ & 5.085 & 0.000 & accepted \\
\hline $\mathrm{H}_{2}$ & $\begin{array}{l}\text { Enterpreneurial Mindset } \rightarrow \text { Enterpreneur } \\
\text { Intention }\end{array}$ & 3.574 & 0.000 & accepted \\
\hline $\mathrm{H}_{3}$ & $\begin{array}{l}\text { Moderating Effect } 1 \rightarrow \text { Enterpreneur } \\
\text { Intention }\end{array}$ & 2.558 & 0.011 & accepted \\
\hline $\mathrm{H}_{4}$ & $\begin{array}{l}\text { Moderating Effect } 2 \rightarrow \text { Enterpreneur } \\
\text { Intention }\end{array}$ & 1.631 & 0.104 & accepted \\
\hline
\end{tabular}

Table 3 shows the summary of hypothesis testing. The first hypothesis, which suspects informal entrepreneurial education having a significant influence on entrepreneurial intention, is accepted, because the value of $\mathrm{T}$ statistics is 5.085, greater than 1.96 , and the $\mathrm{P}$ value is 0.000 , less than 0.050 . So, informal entrepreneurial education has a positive significant influence on entrepreneurial intention. The second hypothesis, which suspects entrepreneurial mindset having a significant influence on entrepreneurial intention, is also accepted, because the value of T statistics is 3.574, greater than 1.96, and the P value is 0.000 , less than 0.050 . So, entrepreneurial mindset has a positive significant influence on entrepreneurial intention.

The third hypothesis, which suspects grit moderating informal entrepreneurial education on entrepreneurial intention, is accepted, because the T statistics is 2.558, greater than 1.96, and the $\mathrm{P}$ value is 0.011 , less than 0.050 . So, grit acts as a moderating variable that strengthen the influence of informal entrepreneurial education to entrepreneurial intention. The fourth hypothesis, which suspects grit moderating entrepreneurial mindset to entrepreneurial intention, is rejected, because the T statistics is 1.631 , less than 1.96 , and the P value is 0.104 , greater than 0.050. Therefore, grit does not act as a moderating variable between entrepreneurial mindset and entrepreneurial intention, or grit does not give any effect between entrepreneurial mindset and entrepreneurial intention.

\section{Conclusion}

Regardless their university majors, the undergraduates' students of Petra Christian University has a high intention to become entrepreneurs. The intention is significantly influenced by the informal education outside university environments. The intention is also significantly influenced by their mindset. Meanwhile, grit, which is often a blend of perseverance and persistence, makes stronger the influence of informal education on entrepreneurial intention. Yet, grit does not give any influences on entrepreneurial mindset and intention. As this is a preliminary study, the results will be the foundation for further researches. The future research will be exploring comprehensively on how the family plays the role in shaping the business mindset and grit. 


\section{References}

[1] Aninda, N.: IBER : 2020 asia hadapi tantangan yang lebih berat. www.bisnis.com, October 29 (2019). Retrieved from https://ekonomi.bisnis.com/read/20191029/9/1164489/iber-2020-asiahadapi-tantangan-yang-lebih-berat

[2] Szerb, L., Lafuente, E., Ács, Z. J., and Márkus, G.: Global entrepreneurship index 2019. The Global Entrepreneurship and Development Institute, Washington (2019)

[3] Gjorgjieska, M. B., Milevska, M., and Jankuloski, B.: Formal and informal education in entrepreneurship and SME management - current situation and tendencies in Macedonia. In Eds. Andrade, J.S., Simões, M.C.N., Stošić, I., Erić, D., \& Hanić, H. Managing Structural Changes Trends and Requirements, Faculty of Economics of the University of Coimbra, Coimbra (2012)

[4] Gibb, A.: Entrepreneurship and Small Business Management: Can We Afford to Neglect Them in the Twenty-First Century Business School?. British Journal of Management, Vol. 7, No. 4, pp. 309-321 (2005)

[5] Hou, F., Su, Y., Lu, M., \& Qi, M.: Model of the Entrepreneurial Intention of University Students in the Pearl River Delta of China. Front. Psychol., April (2019)

[6] Geldhof, G.J., Weiner, M., Agans, J.P., Mueller, M.K., and Lerner, R.M.: Understanding Entrepreneurial Intent in Late Adolescence: The Role of Intentional Self-Regulation and Innovation. Journal of Youth and Adolescence, Vol. 43, pp. 81-91 (2014)

[7] Cui, J., Sun, J.H., and Bell, R.: The impact of entrepreneurship education on the entrepreneurial mindset of college students in China: The mediating role of inspiration and the role of educational attributes. The International Journal of Management Education (2019). Retrieved from https://doi.org/10.1016/j.ijme.2019.04.001

[8] Duckworth, A., and Quinn, P. D.: Development and validation of the short grit scale (Grit-S). Journal of Personality Assessment, Vol. 91, No. 2, pp. 166-174 (2009)

[9] Butz, N. T., Hanson, S., Schultz, P. L., and Warzynski, M. M.: Beyond the Big Five: Does grit influence the entrepreneurial intent of university students in the US?. Journal of Global Entrepreneurship Research, Vol. 8, No. 15, pp. 1-16 (2018)

[10] Singh, J., and Chopra, V. G.: Workplace spirituality, grit and work engagement. Asia-Pacific Journal of Management Research and Innovation, Vol. 14,No. 1, pp. 50-59 (2018)

[11] Rogoff, B., callanan, M., Gutierrez, K. D., and Erickson, F.: The organization of informal learning. Review of Research in Education, Vol. 1, No. 40, pp. 356-401 (2016)

[12] Jeong, S., Han, S. J., Lee, J., Sunalai, S., and Yoon, S. W.: Integrative literature review on informal learning: Antecedents, conceptualizations, and future directions. Human Resource Development Review (2018). Retrieved from https://doi.org/10.1177\%2F1534484318772242

[13] Ireland, R.D., Hitt, M.A., and Sirmon, D.G.: A model of strategic entrepreneurship: the construct and its dimensions. Journal of Management, Vol. 29, pp. 963-990 (2003)

[14] Haynie, J.M., Shepherd, D., Mosakowski, E., and Earley, P.C.: A situated metacognitive model of the entrepreneurial mindset. Journal of Business Venturing, Vol. 25, pp. 217-229 (2010)

[15] Solesvik, M.Z., Westhead, P., Matlay, H., and Parsyak, V.N.: Entrepreneurial assets and mindsets: Benefit from university entrepreneurship education investment. Education + Training, Vol. 55, No. 8-9, pp. 748-762 (2013)

[16] Naumann, C.: Entrepreneurial mindset: A synthetic literature review. Entrepreneurial Business and Economics Review, Vol. 5, No. 3, pp. 149-172 (2017)

[17] Duckworth, A., and Gross, J. J.: Self-control and grit: Related but separable determinants of success. Psychological Science, Vol. 23, No. 5, pp.319-325 (2014)

[18] Tirado, J. L. A., Bojica, A., Martín, F. F., and Hoyle, R. H.: Grit as predictor of entrepreneurship and self-employment in spain. Frontiers in Psychology, Vol. 10, No. 389, pp. 1-12 (2019)

[19] Salami, S. O.: Examining the emerging entrepreneurial mindset in adolescence: A study in Nigeria. International Journal of Psychology, Vol. 54, No. 1, pp. 70-79 (2019)

[20] Cao, V. Q., and Ngo, T. T. T.: Linking entrepreneurial intentions and mindset models: A comparative study of public and private universities in vietnam. Gadjah Mada International Journal of Business, Vol. 21, No. 2, pp. 115-133 (2019) 
[21] Garson, G.D.: Partial Least Squares: Regression \& Structural Equation Models. NC: Statistical Publishing Associates, Asheboro (2016)

[22] Chin, W.W., and Newsted, P.R.: Structural equation modeling analysis with small samples using partial least squares. In Ed. Hoyle, R.H. Statistical Strategy for small-sample research. Sage Publication, London (1999) 